\title{
Learn Single Substance and Mixed Substances with Demonstration Based Videos: Learning Media Feasibility
}

\section{Simon Hadiwinata ${ }^{*}$, I Made Citra Wibawa ${ }^{2}$}

1,2 Universitas Pendidikan Ganesha Singaraja, Indonesia

\section{ART I C L E I N F O}

Article history:

Received March 03, 2021

Revised March 09, 2021

Accepted May 03, 2021

Available online May 25, 2021

Kata Kunci:

Video Pembelajaran, Zat Tunggal

Dan Zat Campuran

Keywords:

Video Lessons, Single Substance And Mixed Substance

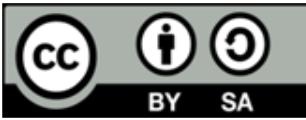

This is an open access article under the CC BY-SA license.

Copyright (C) 2021 by Author. Published by Universitas Pendidikan Ganesha.

\begin{abstract}
A B S T RAK
Penelitian ini dilatarbelakangi oleh kurang efektifnya dan inovasi dari guru untuk menciptakan media video pembelajaran dimasa pandemi yang menggunakan model pembelajaran daring/dalam jaringan. Penelitian ini bertujuan untuk menghasilkan video pembelajaran berbasis demonstrasi yang sudah teruji validitasnya pada topik zat tunggal dan zat campuran kelas $V$ sekolah dasar. Penelitian ini merupakan penelitian pengembangan yang dilaksanakan dengan menggunakan model $4 D$ dengan tahapan-tahapan yaitu: define (pendefinisian), design (perancangan), develop (pengembangan), disseminate (penyebaran). Subjek penelitian ini adalah 2 ahli materi, 2 ahli media, dan 2 ahli praktisi. Sedangkan objek penelitian ini yaitu pengembangan video pembelajaran berbasis demonstrasi topik zat tunggal dan zat campuran untuk siswa kelas V Sekolah Dasar. Pada penelitian pengembangan ini menggunakan metode analisis deskriptif kualitatif dan kuantitatif. Data yang diperoleh kemudian dilakukan analisis untuk mengetahui skor validitas video pembelajaran berbasis demonstrasi. Nilai rata-rata validitas video pembelajaran berbasis demonstrasi dari ahli materi sebesar 97,5\% dengan kategori sangat baik, dari ahli media sebesar 95\% dengan kategori sangat baik, dan dari praktisi sebesar 87\% dengan kategori baik. Berdasarkan analisis tersebut maka dapat dikatakan bahwa video pembelajaran berbasis demonstrasi yang dikembangkan pada topik zat tunggal dan zat campuran dinyatakan valid digunakan dalam pembelajaran di kelas $V$ sekolah dasar.
\end{abstract}

\section{A B S T R A C T}

This research is motivated by the ineffectiveness and innovation of the teacher to create instructional video media during the pandemic era that uses an online learning model. This study aims to produce demonstration-based learning videos that have been tested for their validity on the topic of single substances and mixed substances in fifthgrade elementary schools. This research is development research carried out using the 4D model with the following stages: define, design, develop, disseminate. The subjects of this study were two material experts, two media experts, and two practitioner experts. At the same time, the object of this research is the development of demonstration-based learning videos on the topic of single substances and mixed substances for fifth-grade elementary school students. This development research using qualitative and quantitative descriptive analysis methods. The data obtained were then analyzed to determine the validity score of demonstration-based learning videos. The average value of demonstration-based learning videos from material experts was $97.5 \%$ in the very good category, from the media experts by $95 \%$ with the very good category, and from the practitioners by $87 \%$ with the good category. Based on this analysis, it can be said that demonstration-based learning videos developed on the topic of single substances and mixed substances are declared valid and can be used in learning in fifth-grade elementary schools.

\section{INTRODUCTION}

In the current reality, the world of education is being hit by the COVID-19 disaster. Corona Virus Disease / COVID-19 is a new pandemic disease that was first reported to have emerged in China, Wuhan, China, on December 31,2019, that attacks the human respiratory system, that spreads very quickly (D. Handayani et al., 2020; Kolta \& Ghonimy, 2020). This virus paralyzed the economic system in Indonesia, including the education sector, which resulted in all schools implementing an online or online learning system (Asmuni, 2020; Dewi, 2020). During online learning, all schools instantly switch from learning face to fully online learning, so it has been stressful for many instructors and students who prefer learning directly (Hew et al., 2020; Satrianingrum \& Prasetyo, 2020). Online learning is a form of delivering conventional learning material via the internet. Online learning becomes a media delivery of content between teachers and students on the current pandemic (Bariah, 2019; N. A. Handayani, 2021). The transition from face-to-face learning to online learning requires adaptation for teachers and students. The teacher must present an attractive learning system to understand the material provided by providing 
media such as learning videos. Instructional videos can combine and integrate various methods and learning techniques that effectively help students learn and increase student learning outcomes and motivation (Ziden \& Rahman, 2013).

During the current pandemic, teachers must be clever in choosing learning media used in the learning process to have innovation not to be bored. Learning objectives can foster interest and encourage students to learn to change positive abilities, attitudes, or behaviors (Atsani, 2020; Pane \& Dasopang, 2017). This learning method certainly has advantages in increasing student interest, increasing student participation, improving the quality of discussions, and encouraging online interaction in the learning process by displaying simple animated videos to be happy. The material provided is easy to understand. This way of learning the atmosphere is almost the same as in class because students can still see the educator's face displayed in the video (Ningthoujam, 2016; Yu, 2021). Learning carried out in elementary schools uses online learning with parental guidance to have the flexibility of learning time to study anywhere and anytime (Dewi, 2020). Online learning is learning that is carried out using the internet as an innovation in education that involves elements of information technology in the learning process that can be done massively with an unlimited number of participants to distribute knowledge (Parid \& Utami, 2021; Syarifudin, 2020). It is done to avoid direct contact between educators and students where conventional or face-to-face learning systems can expand the spread of the Covid-19 virus.

However, conditions in the field show that from the data from a preliminary study conducted on the fifth-grade elementary school homeroom teacher in Gugus V, Kecamatan Buleleng, 2020/2021 academic year on November 10 and 11, 2020.58\% of teachers stated that the learning video content in material exposure was not accompanied by demonstrating direct material, especially on science concepts that require a practicum. It can be the cause of the ineffectiveness of the learning process so that students cannot understand the material well. With the demonstration video demonstrated, it is hoped that students can focus more on the learning material and develop mastery of the concept of the material. The demonstration model is a practice demonstrated by the teacher. It can improve the learning interaction process. Students can focus their attention on the lessons given and participate actively and develop their skills. One way that can be done to help teachers during teaching during this pandemic is by making instructional media videos (Nanda et al., 2020). Facilities and infrastructure to support the online learning process are still lacking and limited (Zainal, 2020). It is the cause of the learning process's ineffectiveness that makes students do not understand the material being taught in the current pandemic. A well-planned online learning model is very different from emergency online learning. To choose the right learning video, educators need to consider learning media from the media and the user sides to use learning media appropriately. Of course, it can help students better understand the learning material provided and increase student involvement in learning and improve learning achievement during the online learning process (Abuhassna et al., 2020; Sari, 2019).

Learning media is an application of learning technology that can be a learning resource to help teachers overcome time and space limitations and generate enthusiasm for learning and accelerate students' learning process (Abidin, 2016; Nurrita, 2018). Appropriate media can accelerate students 'understanding of the material presented or stimulate students' thinking to improve student learning outcomes (Yulia, 2013). Learning media occupies a strategic position in the learning process because it becomes an intermediary for knowledge information from teachers to students. There are many benefits provided by learning media to students (Asmara, 2015). Learning media that is on-trend and much liked by students uses instructional videos, as conveyed by (Majerek, 2014). Current trends in science learning require instructional media such as instructional videos to keep up with ongoing trends. The same is conveyed by (Iqbal et al., 2019). Online video learning is currently a trend with a very rapid increase. Based on the problems found, efforts that can be made to overcome the shortage of these media are that demonstration-based learning videos need to be developed to improve the quality of learning. Learning videos are diverse and different virtual lessons that can capture and present information that can enable students to understand information better and understand because students both hear and see the material being taught (Boateng et al., 2016). This study creates a demonstration-based learning video product that is feasible to use so that there are differences in students before and as easy as using instructional video media. The expected research objective is to produce demonstration-based learning video media that has been tested for validity. After this learning video, they can understand the learning given to be more meaningful, especially in the online learning period. By developing demonstration-based learning video media, it can increase student motivation and interest in taking part in learning that can improve student learning outcomes. 


\section{METHOD}

This research is the development of instructional media designed in demonstration-based learning videos. The 4D model consists of 4 stages: Define, Design, Develop, Disseminate (Tegeh et al., 2019). The Define stage is carried out through needs analysis, student characteristic analysis, analysis of existing videos, and curriculum analysis. The Design stage is carried out by carrying out design concepts, media concepts, and draft concepts. The Develop stage is carried out through the production stage, implementation stage, and evaluation stage. The Disseminate stage is carried out when the demonstration-based learning video has been tested for validity by uploading demonstration-based learning videos via YouTube. The subjects in the study were two material experts, two media experts, and two practitioners as teachers who would later use the instructional videos. This development research used qualitative and quantitative descriptive analysis methods. This development research used a qualitative descriptive analysis method to process data from comments, responses, criticisms, and suggestions based on tests of experts on media developed using a questionnaire or questionnaire. This analysis was used to know an overview of data distribution based on the expert assessment sheet scores. Quantitative descriptive analysis is used to process data from the questionnaire in scores and process the assessment results. The instrument in this study must meet the validity test requirements to reflect a good instrument. The stages that must be carried out to produce a good instrument are: 1) making the instrument grid in the form of a table, 2) consulting with the supervisor, and 3) compiling the instrument. The demonstration-based learning video validation instrument is modified (Andriawan \& Suparman, 2015) presented in Table 1, Table 2, and Table 3. The instrument used in this development research uses a graded scale or rating scale to make it easier for researchers to find out the respondent's opinion.

Table 1. Material expert instrument

\begin{tabular}{llllc}
\hline No & \multicolumn{1}{c}{ Aspect } & \multicolumn{1}{c}{ Indicator } & Number & Total \\
\hline 1 & Learning & Learning objectives & $1,2,3$ & 3 \\
& & Delivery of material & $4,5,6,7$ & 4 \\
& \multirow{3}{*}{ Material } & Motivating quality & $8,9,10,11$ & 4 \\
& & Material relevance & $12,13,14$ & 3 \\
& & Material selection & $15,16,17,18$ & 4 \\
\hline Total & & & $\mathbf{1 8}$ \\
\hline
\end{tabular}

Source: Modified from (Andriawan \& Suparman, 2015)

Tabel 2. Media expert instrument

\begin{tabular}{llllc}
\hline No & \multicolumn{1}{c}{ Aspect } & \multicolumn{1}{c}{ Indicator } & Number & Total \\
\hline 1 & Media quality & Video quality displayed & $1,2,3,4$ & 4 \\
& & Ease of use & 5,6 & 2 \\
& & Clarity of sound and text & $7,8,9,10$ & 4 \\
2 & \multirow{2}{*}{ Language use } & The quality of language use & $11,12,13$ & 3 \\
& & The suitability of the placement of the & 14,15 & 2 \\
& \multirow{3}{*}{ Media display } & sentence & 16,17 & 2 \\
& & Video presentation & $18,19,20$ & 3 \\
\hline Total & Layout & & $\mathbf{2 0}$ \\
\hline
\end{tabular}

Source: Modified from (Andriawan \& Suparman, 2015)

Table 3. Practitioner's Instrument

\begin{tabular}{llllc}
\hline No & \multicolumn{1}{c}{ Aspect } & \multicolumn{1}{c}{ Indicator } & Number & Total \\
\hline 1 & Learning & Learning objectives & $1,2,3$ & 3 \\
& & Delivery of material & $4,5,6,7$ & 4 \\
& & Motivating quality & $8,9,10,11$ & 4 \\
2 & \multirow{2}{*}{ Material } & Material relevance & $12,13,14$ & 3 \\
& \multirow{2}{*}{ Media quality } & Material selection & $15,16,17,18$ & 4 \\
& & Video quality displayed & $21,22,23,24$ & 4 \\
& & Ease of use & 25,26 & 2 \\
4 & \multirow{2}{*}{ Language use } & Clarity of sound and text & $27,28,29,30$ & 4 \\
& & The quality of language use & $31,32,33$ & 3 \\
& & The suitability of the placement of the & 34,35 & 2 \\
\hline
\end{tabular}




\begin{tabular}{|c|c|c|c|c|}
\hline No & Aspect & Indicator & Number & Total \\
\hline & & sentence & & \\
\hline \multirow{2}{*}{\multicolumn{2}{|c|}{ Media display }} & Video presentation & 36,37 & 2 \\
\hline & & Layout & $38,39,40$ & 3 \\
\hline Total & & & & 38 \\
\hline
\end{tabular}

Source: Modified from (Andriawan \& Suparman, 2015)

The analysis method used in this research was descriptive qualitative analysis method and quantitative descriptive. In this development research, a qualitative descriptive analysis method was used to process data from comments, responses, criticisms, and suggestions based on tests from experts on the media developed using a questionnaire or questionnaire. Meanwhile, quantitative analysis methods were used to process data from questionnaires in scores and process student performance assessments through observation sheets. Data analysis used in this study was to calculate the percentage of each subject and continued by calculating the percentage of the entire subject. To be able to make decisions and give meaning, the provisions in Table 4 are used.

Table 4. Conversion table of achievement levels with a scale of five

\begin{tabular}{cc}
\hline Achievement Rate (\%) & Criteria \\
\hline $90-100$ & Very good \\
$75-89$ & Good \\
$65-74$ & Enough \\
$55-64$ & Not good \\
$0-54$ & Bad \\
\hline
\end{tabular}

(Tegeh \& Kirna, 2010)

\section{RESULT AND DISCUSSION}

\section{Result}

\section{Define Stage}

The defining stage was taken through several stages: 1) needs analysis, 2) video analysis, 3) student characteristics analysis, 4) curriculum analysis. 1) The needs analysis was carried out in developing the media used in SD Gugus V, Kecamatan Buleleng, using a questionnaire and interview method. Based on the results of the questionnaire, it was found that (1) $100 \%$ of teachers stated that using learning media in teaching. (2) $72 \%$ of teachers stated that the instructional videos used were made by themselves but were obtained from the internet. (3) $58 \%$ of teachers stated that the learning video content in the form of material presented was not accompanied by direct demonstration of the material, especially on science concepts that required practical. 2) Video analysis was carried out to obtain information about good video quality. In developing this video, several criteria were used: aspects of media quality, language use, and aspects of media display. 3) Analysis of Student Characteristics based on Piaget's theory of cognitive development states that elementary school students were at the concrete operational stage. The learning process requires concrete objects. Based on this theory, it can be said that learning media is needed in the learning process to take place. 4) Curriculum analysis was carried out by analyzing core competencies, basic competencies, and indicators in teacher books and student books used as references in developing video media.

\section{Design Stage}

After the defining stage, it is continued with the design stage. Three concepts must be designed at the design stage: 1) Design Concept, 2) Media Concept, 3) Text Concept. 1) The design concept in the demonstration-based learning video has three parts, the opening, the core, and the closing. 2) Media Concept This was done by selecting images, sounds, text, music, transitions, animations, and video backgrounds so that the video displayed was effective and interactive. 3) The script concept was made so that the demonstration-based learning video becomes more structured.

\section{Development Stage}

There are three stages at the development stage: 1) Production Stage, 2) Implementation Stage, 3) Evaluation Stage. The Production Stage is the stage of the process of making demonstration-based learning videos based on a script that has been designed. There are three parts to the learning video process: opening, core, and closing. The video opener consists of an intro made with an animation 
containing text in the form of an opening greeting, personal identity, title, and learning objectives. Greeting students was made with the narrator standing in front of the camera. Greeting students with a background image of the classroom with a medium shot type assisted by a greenscreen. The video background becomes the classroom, and linking the material with the environment is made the same as the greeting section of students in Figure 1. The core part of the video consisted of giving problems to students as well as the part greeting students and relating the material to the environment; prepare tools and materials with an extreme close up view, showing one by one the tools and materials needed; and homogeneous compound practicum made equal to the appearance of preparing tools and materials; Heterogeneous mixed substance practice is made the same as the display of preparing tools and materials and homogeneous mixed substance practice that can be seen in Figure 2. Closing consisted of concluding the overall practicum and answering the problems given initially in a classroom setting. Give assignments as a follow-up with table views that students will do. Closing the video by saying hello and thank you with the appearance of the narrator standing in front of the camera as a classroom background. The outro displayed with animated text that hopefully is useful, and the closing greetings are shown in Figure 3.

At the implementation stage, demonstration-based learning videos have been made tested on material experts, media experts, and practitioners as teachers who will use the learning videos made. Data from the validity test results were processed and analyzed to determine the validity of the video developed. Data analysis was carried out by calculating the average score obtained through the assessment sheet filled out by experts. The data converted with five scale conversion guidelines to determine the qualifications of the validity of the video being developed. From the data analyzed, the material expert validation scored $97.5 \%$ in the very good category. The validation media experts scored $95 \%$ in the very good category, and the practitioner scored $87 \%$ in the good category. From the assessment of material experts, media experts, and practitioners, it can be concluded that the demonstration-based learning videos that have been made can be said to be suitable to use in the learning process. The evaluation stage was carried out aimed at perfecting demonstration-based learning videos. Several parts to the video improved based on the input, suggestions, and comments provided by material experts, media experts, and practitioners, presented in Table 5.

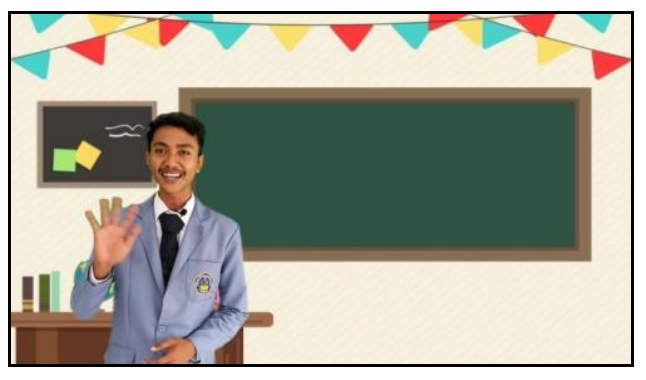

Figure 1. Opening

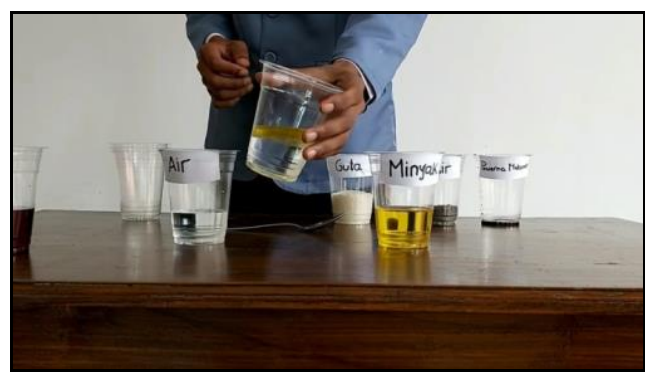

Figure 2. Practicum

Table 5. Input table, suggestions, and comments

\begin{tabular}{cl}
\hline No & Input, suggestions, and comments \\
\hline 1 & Videos are added with more interesting backgrounds \\
2 & Videos are added with more interesting backgrounds \\
3 & 1. 1. In general the video is very good \\
2. 2. The assignment needs to take longer to run and provide brief instructions \\
3. $\quad$ 3. 08:50 when explaining, show me the pictures \\
4. 4. At the end of the video, give a thank you \\
4 The presentation of the material is good. Give more examples \\
5 During the experimental activities, it is expected that faces are shown to attract students
\end{tabular}

\section{Disseminate Stage}

The dissemination stage was carried out by uploading demonstration-based learning videos made, revised, and tested for validity via YouTube. The video that has been distributed has received positive comments. It showed that this demonstration-based learning video could be received well. The video distributed was expected to help teachers in the teaching and learning process, especially on single substances and mixed substances in fifth grade. 


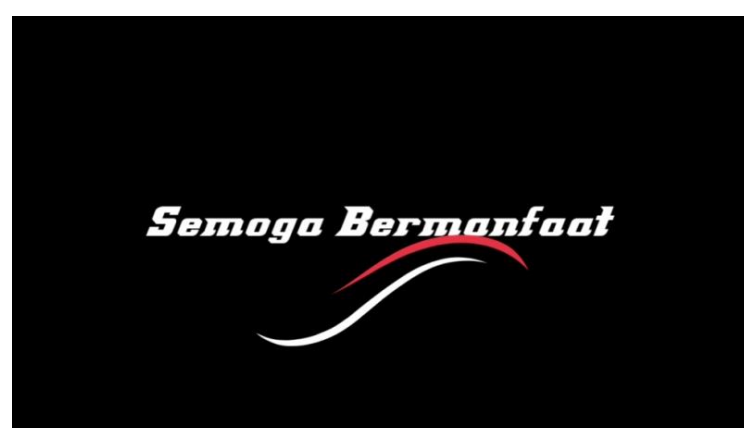

Figure 3. Closing

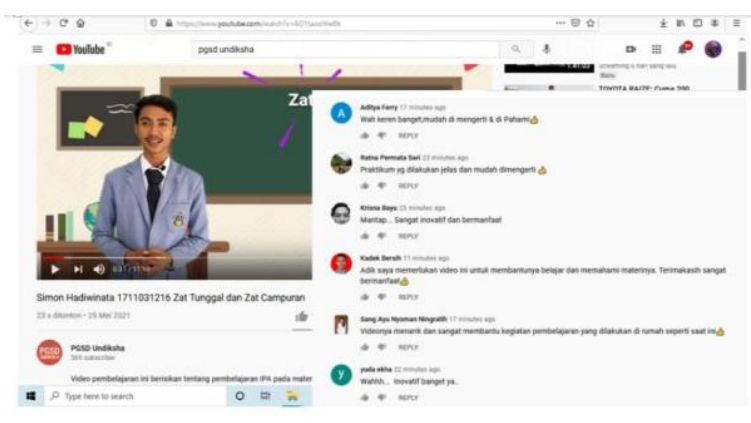

Figure 4, Comments on YouTube

\section{Discussion}

This development research produces demonstration-based instructional video media on the topic of single substances and mixed substances. This learning video contains a demonstration or displays a demonstration in the form of a simple experiment regarding a single substance and a mixture of substances. Demonstration-based learning videos were made more attractive by adding pictures, text, effects, transitions, music, and animation to make it easier and more enjoyable for students to learn. The guidelines used in developing this demonstration-based instructional video media was the 4D model that consisted of 4 stages: Define, Design, Develop, and Disseminate. The Define stage was carried out through needs analysis, student characteristics analysis, existing video analysis, and curriculum analysis. The development of demonstration-based learning videos based on the needs analysis results in elementary schools that were carried out in Gugus V, Kecamatan Buleleng, can be a solution to solve problems in the field. Through demonstration-based learning videos, students can directly observe and try simple experiments on instructional videos to make it easier for students to understand the material. So that it was following the characteristics of elementary school students in age 7-11 years or at the concrete operational stage, so that the students' way of thinking has begun to be stable and logical (Dantes, 2014). The characteristics of high-class students, their interest in concrete life, so that there is a tendency to compare practical work so that students in high classes need a practical learning medium to learn concretely, such as demonstration-based learning videos (Djamarah, 2008). Based on the defining stage, it was found that demonstration-based learning videos on the topic of single substances and mixed substances in fifth grade were very important to be developed. According to research from (Warkintin \& Mulyadi, 2019), the stages and results delivered the results in learning media development based on needs analysis, gathering information on both students and curriculum, and problem analysis continued with the preparation of a product draft.

The Design stage was carried out by carrying out design concepts, media concepts, and draft concepts. The video design concept used a 16: 9 ratio with a 720p size of 7-12 minutes. It was not boring for students and edited using the KineMaster application. The lesson video was divided into three parts: the opening part, the core part, and the closing part. The media concept was to choose a video composer, including the music used, images, text, effects, transitions, animations, and video backgrounds to produce interesting learning videos for students. The video script describes each scene, the narrative, the type of shot, the tools used in making the video, and the duration of each scene. The Develop stage was carried out through the production stage, implementation stage, and evaluation stage. The production process used a video script reference that has been made. The product in the form of a video can be structured. After the production stage, it was continued with trials with two material experts, two media experts, and two expert practitioners. The learning videos can be suitable for use in the learning process seen from the assessments by material experts, media experts, and practitioners. Trials carried out the implementation stage with material experts, media experts, and practitioners as teachers who would use it to determine the feasibility of the learning videos made. At the evaluation stage, improvements were made from the input that material experts had given, media experts, and practitioners as teachers who would use the learning videos to make them more perfect for learning. The Disseminate stage was carried out when the demonstration-based learning video has been tested for validity by uploading demonstration-based learning videos via YouTube and in the form of articles. It was hoped that the learning videos that have been made could help teachers in teaching during the current pandemic and make it easier for students in the learning process so that learning objectives can be achieved properly.

The demonstration-based learning video media can be good and have the advantages of learning videos widespread on social media. It can be seen from the results of the validity analysis of the material experts that learning objectives were very good at displaying learning objectives in video media, learning objectives following basic competencies. The material presented in video media was following the 
learning objectives. In terms of material delivery, the material on the learning video has been conveyed, the material conveyed coherently, the choice of words followed the material presented, and the material on the learning video conveyed attractively. In terms of motivating quality, the delivery of material on the video can attract learning interest, the presentation of material on the video can make students listen well, the presentation of material can foster curiosity, and the presentation of material in the learning video was very good in increasing student activity. In the material aspect, in terms of material relevance, the material presented was following the basic competencies, was following the level of student development, and the level of difficulty of the material presented was following the level of the student. In terms of material selection, it was very good at conveying the material in the learning media. The material presented can stimulate the attractiveness of students to learn. The depth of the material was sufficient for students to learn the next material, and the truth of the material presented can be accounted for. From the advantages that have been described above, there were the obstacles faced by researchers, having to adjust to the teacher's schedule at the time of initial observation because schools do online learning so that the teacher implements a picket system to attend school. Another obstacle faced was making videos ineffective for video shooting because it was done in a classroom. They had to repeat the video shooting due to the disturbing sound. However, from the obstacles faced, the researcher was able to complete this research well.

The media experts' validity on media quality regarding the video quality displayed was very good at displaying images/videos with the material being taught. The video display supported student learning and understanding, the clarity of video content, and displays the image/video clearly or has a good resolution. In terms of ease of use, it is very easy to use/operate video media, and the learning videos that have been made can be used on various supporting devices. In terms of voice and text clarity, the clarity of sound/music effects was very good, already using voice/music to make it more attractive, the text used was easy to read properly. It adjusted the text to the narration that was conveyed. In the aspect of language use, in terms of the quality of language use, language is easy to understand, accuracy in writing, and the choice of language used. In the learning videos, it was clear in using words and terms. In terms of the suitability of sentence placement, it was very good to set the spacing of each sentence in the displayed text. The suitability of the shape and size of the letters in the text was very good in the learning videos. In the aspect of media display in terms of a video presentation, the color combination and video display design were very good and had high appeal. The instructional video layout, layout compatibility, score layout, and image layout were very good for the learning process.

From the advantages of instructional video media described and tested to experts, it can be concluded that the instructional video media made have very good validity to be said to be feasible to be distributed to social media. Demonstration-based learning videos on single substances and mixed substances can support the learning process because students can see, hear, and observe the material being learned. (Bahar et al., 2019) stated that thematic learning through demonstration methods is supported by learning videos in good categories and can achieve the desired effectiveness. Technologybased learning, both through learning video media and YouTube for the sake of learning, will still exist and continue to grow, along with the rapidly growing ownership of computers or smartphones in the world of technology-based learning becoming increasingly developed and easily accessible (Anugrahana, 2020). This development research cannot create and provide learning video media that is attractive and tested for its validity. Students' interest in the learning process will be more interactive, effective, and efficient. So, with interesting and interactive instructional video media, the learning objectives will be well achieved. This research has implications, demonstration-based learning videos on single substances and mixed substances in fifth-grade elementary schools whose validity has been tested in the very good category. This learning video can support science learning, especially on the topic of single substances and mixed substances. Demonstration-based learning videos are developed according to elementary school students' characteristics at the concrete operational stage. In the learning process, students need the help of concrete or tangible objects to understand better the material being taught. This learning video can facilitate students in learning so that learning objectives can be achieved optimally.

\section{CONCLUSION}

The demonstration-based learning video media developed can be suitable for use in the learning process, with a very good category seen from the assessment of material experts, media experts, and practitioners. Suggestions that can be conveyed in the development of video media that have been done are to take advantage of instructional video media that can support the learning process. Be more innovative and creative in developing learning media to be much easier and more interesting. The results 
of this study are used as a reference in conducting similar research as a reference for conducting better development research.

\section{REFERENCES}

Abidin, Z. (2016). Penerapan Pemilihan Media Pembelajaran. Edcomtech, 1(1), 9-20. http://journal2.um.ac.id/index.php/edcomtech/article/view/1784.

Abuhassna, H., Al-Rahmi, W. M., Yahya, N., Zakaria, M. A. Z. M., Kosnin, A. B. M., \& Darwish, M. (2020). Development of a new model on utilizing online learning platforms to improve students' academic achievements and satisfaction. International Journal of Educational Technology in Higher Education, 17(1). https://doi.org/10.1186/s41239-020-00216-z.

Andriawan, A., \& Suparman, M. P. (2015). Pengembangan Media Pembelajaran Berbasis Video Demonstrasi Pada Mata Pelajaran Praktik Batu Kelas XI Jurusan Teknik Konstruksi Batu Beton Di SMKN 2 Pengasih. E-Journal Pend. Teknik Sipil Dan Perencanaan, 3(3), 45-47.

Anugrahana, A. (2020). Hambatan, Solusi dan Harapan: Pembelajaran Daring Selama Masa Pandemi Covid-19 Oleh Guru Sekolah Dasar. Scholaria: Jurnal Pendidikan Dan Kebudayaan, 10(3), 282-289. https://doi.org/10.24246/j.js.2020.v10.i3.p282-289.

Asmara, A. P. (2015). Pengembangan media pembelajaran berbasis audio visual tentang pembuatan koloid. JURNAL ILMIAH DIDAKTIKA: Media Ilmiah Pendidikan Dan Pengajaran, 15(2), 156-178. https://doi.org/10.22373/jid.v15i2.578.

Asmuni, A. (2020). Problematika Pembelajaran Daring di Masa Pandemi Covid-19 dan Solusi Pemecahannya. Jurnal Paedagogy, 7(4), 281. https://doi.org/10.33394/jp.v7i4.2941.

Atsani, K. L. G. M. Z. (2020). Transformasi media pembelajaran pada masa Pandemi COVID-19. Jurnal Studi $\begin{array}{lll}\text { Islam, } & \text { 82-93. }\end{array}$ http://ejournal.kopertais4.or.id/sasambo/index.php/alhikmah/article/view/3905.

Bahar, M. A., Trisiana, A., \& Handini, O. (2019). Pengaruh Metode Demonstrasi Di Dukung Video Terhadap Hasil Belajar Pembelajaran Tematik Integratif. Jurnal Sinektik, 2(1), 64-76. https://doi.org/10.33061/js.v2i1.2989.

Bariah, S. K. (2019). Rancangan Pengembangan Instrumen Penilaian Pembelajaran Berbasis Daring. Jurnal Petik, 5(1), 31-47. https://doi.org/10.31980/jpetik.v5i1.445.

Boateng, R., Boateng, S. L., Awuah, R. B., Ansong, E., \& Anderson, A. B. (2016). Videos in learning in higher education: assessing perceptions and attitudes of students at the University of Ghana. Smart Learning Environments, 3(1). https://doi.org/10.1186/s40561-016-0031-5.

Dantes, N. (2014). Landasan Pendidikan Tinjauan dari Dimensi Makropedagogis. Graha Ilmu.

Dewi, W. A. F. (2020). Dampak Covid-19 Terhadap Implementasi Pembelajaran Daring Di Sekolah Dasar. Jurnal Ilmu Pendidikan, 2(1), 55-61. https://doi.org/10.31004/edukatif.v2i1.89.

Djamarah, S. B. (2008). Psikologi Belajar. Rineka Cipta.

Handayani, D., Hadi, D. R., Isbaniah, F., Burhan, E., \& Agustin, H. (2020). Corona virus disease 2019. Jurnal Respirologi Indonesia, 40(2), 119-129. https://doi.org/10.36497/jri.v40i2.101.

Handayani, N. A. (2021). Analisis Pembelajaran IPA Secara Daring pada Masa Pandemi Covid-19. Jurnal Pendidikan Sains Indonesia, 9(2), 217-233. https://doi.org/10.24815/jpsi.v9i2.19033.

Hew, K. F., Jia, C., Gonda, D. E., \& Bai, S. (2020). Transitioning to the "new normal" of learning in unpredictable times: pedagogical practices and learning performance in fully online flipped classrooms. International Journal of Educational Technology in Higher Education, 17(1). https://doi.org/10.1186/s41239-020-00234-X.

Iqbal, M., Latifah, S., \& Irwandani, I. (2019). Pengembangan Video Blog (Vlog) Channel Youtube Dengan Pendekatan Stem Sebagai Media Alternatif Pembelajaran Daring. Inovasi Pembangunan: Jurnal Kelitbangan, 7(2), 135. https://doi.org/10.35450/jip.v7i2.140.

Kolta, M. F., \& Ghonimy, M. B. I. (2020). COVID-19 variant radiological findings with high lightening other coronavirus family (SARS and MERS) findings: radiological impact and findings spectrum of corona virus (COVID-19) with comparison to SARS and MERS. Egyptian Journal of Radiology and Nuclear Medicine, 51(1). https://doi.org/10.1186/s43055-020-00262-7.

Majerek, D. (2014). Application of Geogebra for teaching mathematics. Advances in Science and Technology Research Journal, 8(24), 51-54. https://doi.org/10.12913/22998624/567.

Nanda, H. I., Pratiwi, E. C., Fadila, I. R. N., Maharani, N. A. B., \& Ardono, V. A. P. (2020). Media Edukasi Siswa Usia Dini di Masa Pandemi. SULUH: Jurnal Abdimas, 2(1), 41-51. https://doi.org/10.35814/suluh.v2i1.1554.

Ningthoujam, R. (2016). Construction and importance of video based analyses teaching in physical education by use of window live movie maker. Video Journal of Education and Pedagogy, 1(1), 1- 
13. https://doi.org/10.1186/s40990-016-0003-2.

Nurrita, T. (2018). Pengembangan media pembelajaran untuk meningkatkan hasil belajar siswa. MISYKAT: Jurnal Ilmu-Ilmu Al-Quran, Hadist, Syari'ah Dan Tarbiyah, 3(1), 171. https://core.ac.uk/download/pdf/268180802.pdf.

Pane, A., \& Dasopang, M. D. (2017). Belajar dan pembelajaran. Fitrah: Jurnal Kajian Ilmu-Ilmu Keislaman, 3(2), 333-352. https://doi.org/10.24952/fitrah.v3i2.945.

Parid, M., \& Utami, I. H. (2021). Kerjasama antara dosen dan mahasiswa dalam proses pembelajaran daring. NIZHAMIYAH, XI(1), 58-67. https://doi.org/10.30821/niz.v11i1.926.

Sari, P. (2019). Analisis terhadap kerucut pengalaman Edgar Dale dan keragaman gaya belajar untuk memilih media yang tepat dalam pembelajaran. Mudir: Jurnal Manajemen Pendidikan, I(1), 58-78. http://ejournal.insud.ac.id/index.php/MPI/article/download/27/27.

Satrianingrum, A. P., \& Prasetyo, I. (2020). Persepsi Guru Dampak Pandemi Covid-19 terhadap Pelaksanaan Pembelajaran Daring di PAUD. Jurnal Obsesi : Jurnal Pendidikan Anak Usia Dini, 5(1), 633. https://doi.org/10.31004/obsesi.v5i1.574

Syarifudin, A. S. (2020). Impelementasi Pembelajaran Daring Untuk Meningkatkan Mutu Pendidikan Sebagai Dampak Diterapkannya Social Distancing. Jurnal Pendidikan Bahasa Dan Sastra Indonesia Metalingua, 5(1), 31-34. https://doi.org/10.21107/metalingua.v5i1.7072.

Tegeh, I. M., \& Kirna, I. M. (2010). Metode Penelitian Pengembangan Pendidikan. Undiksha Press.

Tegeh, I. M., Simamora, A. H., \& Dwipayana, K. (2019). Pengembangan Media Video Pembelajaran Dengan Model Pengembangan 4D Pada Mata Pelajaran Agama Hindu. Mimbar Ilmu, 24(2), 158-166. https://doi.org/10.23887/mi.v24i2.21262.

$\mathrm{Yu}, \mathrm{Z}$. (2021). The effects of gender, educational level, and personality on online learning outcomes during the COVID-19 pandemic. International Journal of Educational Technology in Higher Education, 18(1). https://doi.org/10.1186/s41239-021-00252-3.

Yulia, D. (2013). Pengaruh Penggunaan Media Interaktif dan Motivasi Terhadap Hasil Belajar Sejarah Siswa SMA Negeri I Gunung Talang. Jurnal Dimensi, 2(2).

Zainal, N. H. (2020). Tantangan Kebijakan Pembelajaran Jarak Jauh Di Era Pandemi COVID 19. Jurnal Pencerahan, 14(2), 133-151. http://www.jurnalpencerahan.org/index.php/jp/article/view/31.

Ziden, A. A., \& Rahman, M. F. A. (2013). The Effectiveness of Web-Based Multimedia Applications Simulation in Teaching and Learning. International Journal of Instruction, 6(2), 211-222. https://eric.ed.gov/?id=EJ1085400. 